\title{
On Simulium (Pternaspatha), with Description of a New Species (Diptera-Simuliidae)
}

\author{
S Coscarón/ ${ }^{+}$, CL Coscarón-Arias* \\ Facultad de Ciencias Naturales y Museo, 1900, La Plata, Argentina *Facultad de Ciencias Agrarias, 8324 Cinco \\ Saltos, Río Negro, Argentina
}

Simulium (Pternaspatha) diamantinum n. sp. is described from females, males, pupae and larvae, collected at Mendoza, San Juan and Neuquén. Some specimens of this species from Laguna del Diamante were included before by Wygodzinsky and Coscarón (1967) in S. strigidorsum Enderlein. The new species is compared with closely related species of the S. (Pternaspatha) "nigristrigatum group". The following synonym is established: Simulium (Pternaspatha) bachmanni Wygodzinsky \& Coscarón $=$ Simulium (Pternaspatha) nigristrigatum (Enderlein).

Key words: southern Andean blackflies - description - new species - new synonym

Simulium (Pternaspatha) is a peculiar Neotropical subgenus composed of 26 species characteristic of the S. W. of South America on both sides of the Andes Cordillera from the Puna plateau to Patagonia, with one species in the northern Andes in Ecuador.

This subgenus is characterized particularly by the following combination of characters: gray, pollinose females with variable ornamentation on the abdomen; a subquadrate, distally concave, smooth or rugose male distimere; pupa with a high number of trichomes variable in number, length and morphology (filiform to flattened), single spatulate to multirramose; and larva with dark head with mostly negative spots on the cephalic apotome and a deep, angular gular cleft.

Revisionary works on the taxonomy of this subgenus were made by Wygodzinsky and Coscarón (1967), and Coscarón and Wygodzinsky (1972). More recently Wygodzinsky and Coscarón (1979), and Coscarón and Matta (1982) included two new species. Despite the taxonomic studies above there remained some doubts on species identity, mostly because not all stages (especially the pupa) had been described. An example is $S$. strigidorsum Enderlein, known only from type material (2EE) from Juliaca, Puno (Perú). Wygodzinsky and Coscarón (1967) included in this species females from Argentina, that show some differences with specimens from Perú. Another example is $S$. (Pternaspatha) dureti from San Juan, described from a single pharate male, a pupa and

${ }^{+}$Corresponding author. Fax: +54-21-257527

Received 2 January 1996

Accepted 21 August 1996 several larvae (Coscarón \& Wygodzinsky 1972).

From the present study based on females, pupae and larvae from Laguna del Diamante where $S$. (P.) strigidorsum was recorded by Wygodzinsky and Coscarón (1967), and specimens from Neuquen, we conclude that this material is not $S$. strigidorsum, and corresponds to a new species close to $S$. dureti, S. horcochuspi, S. deagostinii and $S$. pichi

The previous incompletely described $S$. (P.) nigristrigatum (Enderlein 1930), is compared with $S$. (P.) bachmanni Wygodzinsky \& Coscarón (1967).

\section{MATERIALS AND METHODS}

Material was collected in the breeding places, and pupae were maintained alive to obtain imagos. The collecting and dissection methodology used was that of Coscarón (1981). Type specimens of S. (Pternaspatha) strigidorsum (E lectotype), and $S$. (P.) nigristrigatum Enderlein (Glectotype, Esyntype) from the Zoologisches Museum of Humboldt University, Berlin were examined.

\section{RESULTS}

Examination of the newly collected material, revision of previously collected specimens and their comparison with type material of $S$. strigidorsum permits us to establish a new taxon that is here described.

\section{Simulium (Pternaspatha) diamantinum n. sp.}

Female: wing length 3.3-3.7 mm. General color gray pollinose. Antennae, maxillary palp and proboscis blackish. Head brown, dark gray pollinose. Frons, clypeus and occiput blackish with gray pollinosity; occiput a little darker with hairs grayish to black in accordance with the light. 
Mesonotum grayish black with a silvery-gray, submedian, lyre-shaped pattern, lighter anteriorly and grayish laterally and posteriorly (Fig. 1); with changing light position the lyre-shaped pattern becomes thicker, and in some lights its anterior border becomes black, to a silky bright light gray. Mesonotum hairs sparse and upright. Scutellum blackish-gray. Scutum and scutellum hairs light gray. Metanotum velvet blackish. Pleura blackish gray. Wings with yellowish veins and brown hairs and spines. Stem of halteres yellowish-brown, the knob yellowish-white. Legs blackish with basal third of femur III, basal half of tibiae I-III, basal half of basitarsus II and 3/4 of basitarsus III and base of tarsites II-III light brownish. Distribution of pigmentation of hind leg as Fig. 3. Abdomen light grayish pollinose, tergite I dark grayish; black subtriangular median spots on tergites II-V, lighter and pollinose on VII, and 1+1 lateral, blackish, subrectangular spots not reaching posterior border on tergites IV-V (Figs 4-5). Hairs of pleural tuft light gray. Frons as Fig. 6. Fronto-ocular triangle about as long as wide (Fig. 7). Sensory vesicle of palp about 1/3-1/4 of basal articles, its structure as in Fig. 8. Antenna and cibarium as $S$. dureti, typical of the subgenus Pternaspatha. Mandible with $25+8-30+9$ teeth, and maxilla $23-25$ teeth. Sc with 3-5 setae. Base of $R$ without setae; $R_{1}$ and $R_{s}$ with setae and spines arranged in one irregular row. Shape and proportion of articles of leg III as shown in Fig. 2. Without calcipala; ratio of length to width of posterior basitarsus = 7.2-7.6 (Fig. 3). Claws with well developed basal tooth (Fig. 9). Eighth sternite well sclerotized, with 34-40 hairs on each side, gonapophysis subtriangular (Fig. 10). Paraproct and cercus as in Fig. 11. Genital fork as in Fig. 12; spermatheca with small internal spines. Male: wing length $2.8-3.0 \mathrm{~mm}$. Head coloration as in female. Scutum black-grey with $1+1$ subtriangular spots anteriorly (Fig. 13); with light anterior to specimen $1+1$ anterior gray pollinose spots occupying anterior third. Decumbent, silky grayish hairs sparsely covering scutum. Abdomen blackish with 1+1 large gray spot on tergites II, smaller on tergites VII-VIII, VI and IX mostly grayish except for a small and short median darker spot. Pleura, halteres and wings as female. Legs yellowish brown with light gray hairs; blackish brown on coxae, apex of femur III, apex of tibiae, all of basitarsus I, distal third of basitarsi II and III and tarsites. Hind basitarsus three times as long as wide; calcipala absent (Fig. 14). Genitalia very close to species of $S$. (Pternaspatha) "nigristrigatum group"; distimere with abundant tubercles (Fig. 15).

Pupa: cocoon shoe-shaped with well developed antero-ventral bridge (Fig. 16); surface generally smooth, but some specimens with small sand granules incorporated. Cocoon closely woven. Respiratory organs covered basally by walls of cocoon. Length of cocoon 3.8-4.0 mm at dorsum, maximum length along base $5.2-6.0 \mathrm{~mm}$, length of body 4.0-4.7 mm, of gills $2.2-3.3 \mathrm{~mm}$. Respiratory organ with eight filaments, position of basal branching as Fig. 17. Frontoclypeus and thorax with 5001000 platelets (Fig. 18) those of thorax slightly pointed, especially on the posterior border (Fig. 19), others rounded with a smooth (Fig. 20) or slightly rough surface (Fig. 21); trichomes filiform with 4-8 branches, 5-15 frontal and 3-7 facial trichomes on each side in a continuous group. Length of frontal trichomes $0.19-0.23 \mathrm{~mm}$; thoracic trichomes $0.24-0.35 \mathrm{~mm}$ in number of $160-220$, with 6-10 filiform branches (Fig. 22). Chaetotaxy of abdomen following the general pattern of $S$. (Pternaspatha) species.

Larva: maximum length 7.5-8.5 mm. Head width $0.7 \mathrm{~mm}$. Color dark, greenish brown, ornamentation and shape in accordance to Fig. 23. Integument smooth. Cephalic apotome brown with negative spots without well defined borders (Fig. 24). Antennae dark brown; ratio of length of segments I-III = 1:1.8-1.9:1.2-1.3 (Fig. 25). Cephalic fans with 35-39 combs. Rays of internal border of combs of variable length 3-5 short rays alternating with one longer ray. Mandible with 4-6 secondary teeth arranged in several rows (Figs 26-27). Maxillary palp with 4-5 papillae distally. Teeth of hypostomium border as Fig. 28; 5-6 lateral serrations. 15-17 lateral setae arranged in 1-2 rows; disc of hypostomium with 3-5 dispersed setae. Hypostomial bridge short, ratio hypostomium/ hypostomial bridge $=1.4-1.5$. Comb of pseudopod with about 43-54 teeth arranged in 12-14 groups (Fig. 29). Anal sclerite without scales but with isolated trichomes as in Fig. 30. Crochet ring with about 94-100 rows, each composed of about 15-17 hooks. Anal gills with 5-7 lobules on each of the three well developed lobes (Fig. 31).

Material examined: Argentina, Mendoza, Laguna del Diamante, 3,350-3,400 m, 27-I-95, coll. Coscarón $1 \mathrm{E}$ holotype; 77E paratypes; same locality 3,380 m, 27-I-55, coll. Aczel 10 E paratypes; same locality, río Diamante 3,300 m 27-I-95: 4 pupae, 3 larvae in late stage, 8 immature larvae; Neuquén Route 40, 3 $\mathrm{km}$ South of Buta Ranquil, 1,200 m 22-IX-75, Coscarón: $1 \mathrm{G}$ allotype $3 \mathrm{E}$ and $5 \mathrm{G}$ reared, 30 larvae, 20 pupae; San Juan, Tocota. 2,400 m one pharate male, one pupa previously identified as $S$. (P.) dureti. Type material in Museo La Plata. One female cited by Coscarón and Wygodzinsky (1972) as S. strigidorsum from Argentina: Chubut, Alto río Senguerr, 12-II-64, Bejarano, in the 


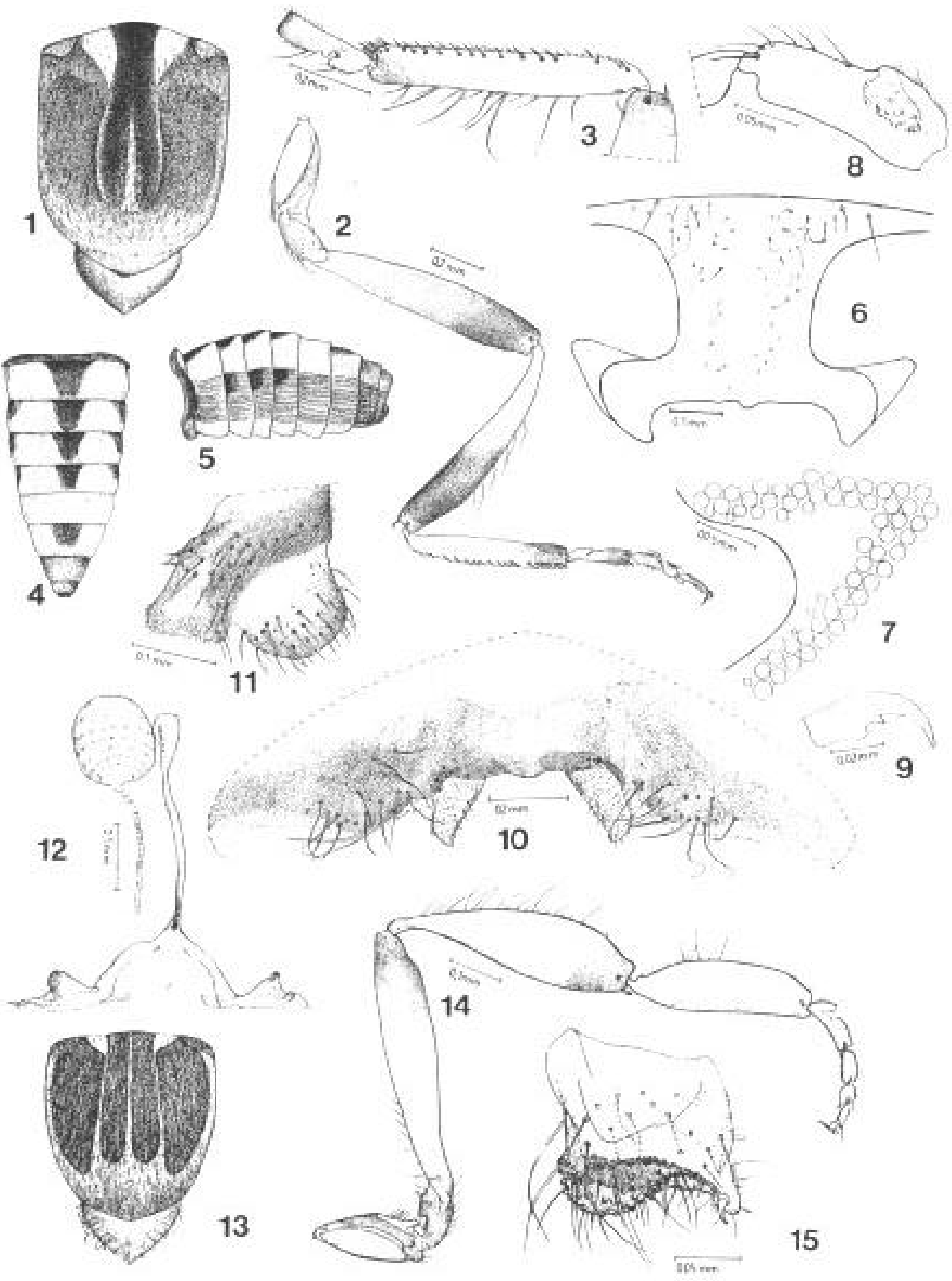

Simulium diamantinum - Figs 1-12: female. Fig. 1: scutum, dorsal view. Fig. 2: hind leg. Fig. 3: posterior basitarsus. Fig. 4: abdomen, dorsal view. Fig. 5: abdomen lateral view. Fig. 6: front. Fig. 7: fronto-ocular triangle. Fig. 8: palpus basal article with sensorial organ. Fig. 9: claw. Fig. 10: VIII sternite and gonapophysis. Fig. 11: paraproct and cercus. Fig. 12: genital fork and spermatheca. Figs 13-15 male. Fig. 13: scutum. Fig. 14: hind leg. Fig. 15: distimere. 


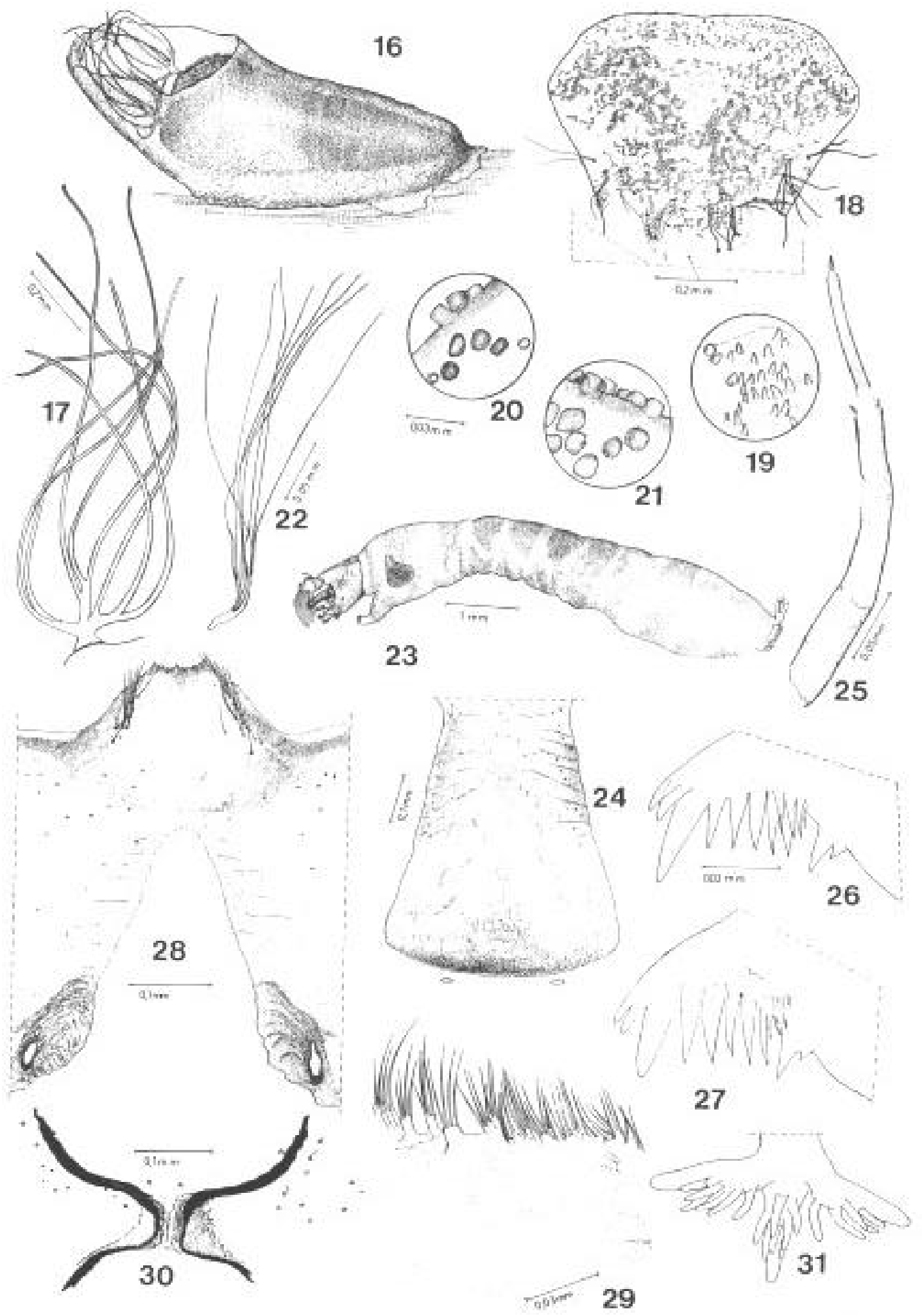

Simulium diamantinum - Figs 16-22: pupa. Fig. 16: general aspect. Fig. 17: respiratory filaments. Fig. 18: frontoclypeus. Figs 19-21: thorax platelets. Fig. 22: thorax trichome. Figs 23-31: larva. Fig. 23: general aspect. Fig. 24: cephalic apotome. Fig. 25: antenna. Figs 26-27: dentary portion of mandible. Fig. 28: hypostomium and angular cleft. Fig. 29: pseudopody comb. Fig. 30: anal sclerite. Fig. 31: anal gills. 


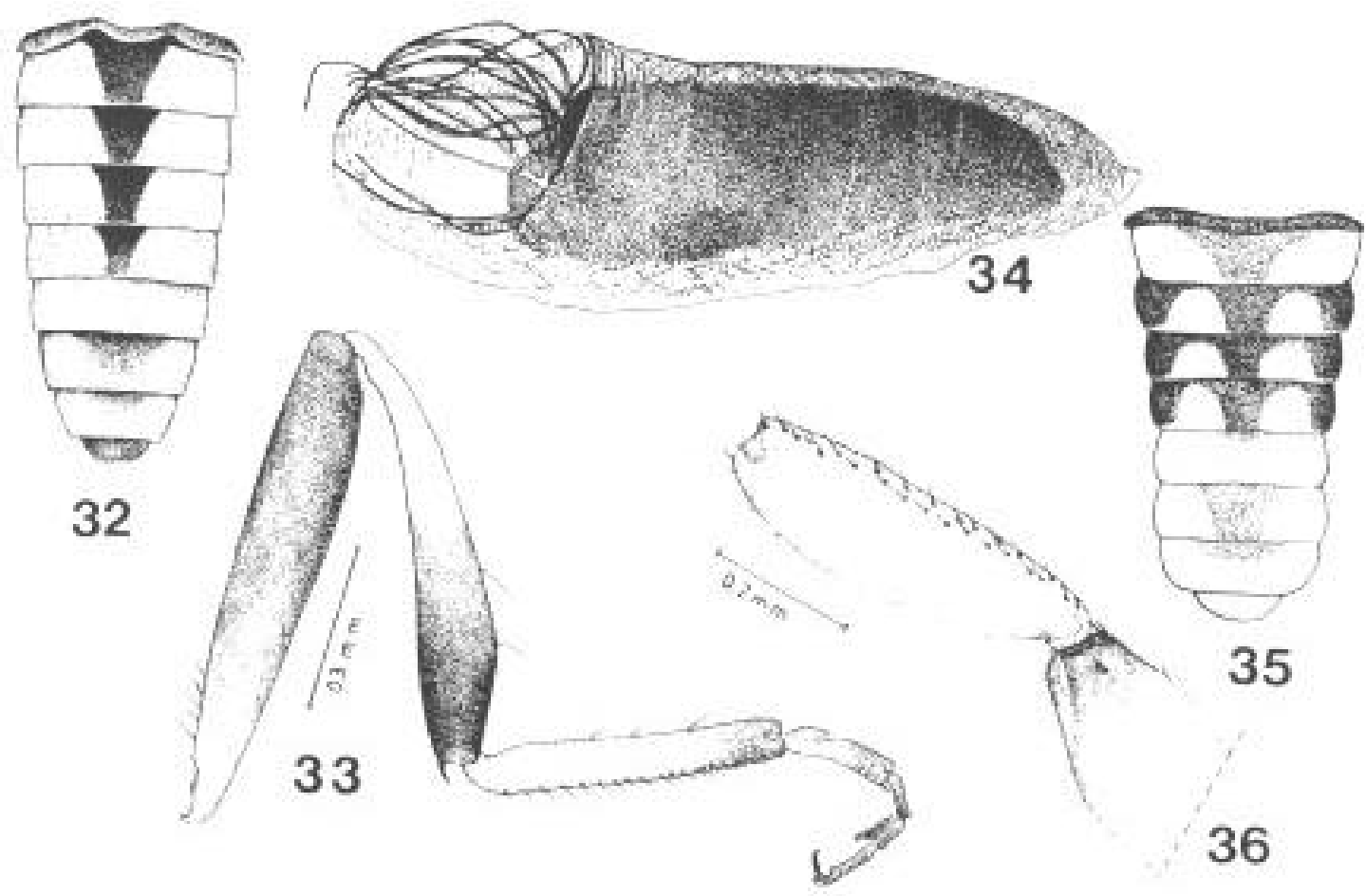

Simulium strigidorsum, female. Fig. 32: abdomen in dorsal view. Fig. 33: hind leg. S. horcochuspi. Fig. 34: pupa, general aspect. S. bachmanni. Fig. 35: abdomen of female, dorsal view. S. nigristrigatum lectotype male. Fig. 36: posterior basitarsus.

Instituto Nacional de Microbiología (Buenos Aires) has been lost.

Bionomics: females are anthropophilic and a biting pest in Laguna del Diamante area, a tourist resort frequented by fisherman. Larvae and pupae were collected on Potamogeton at a short distance from the breeding place in the Diamante river. At the collection site, the river is clear with slow current. At San Juan (Tocota), the breeding ground was in a small creek with a strong current and in northern Neuquén in a medium sized creek.

\section{DISCUSSION}

After re-examination of the female lectotype of $S$. (P.) strigidorsum Enderlein and comparison with new material from Laguna del Diamante the following differences are shown in Table I.

Male, pupa and larva of $S$. strigidorsum are unknown. There are also similarities and differences between $S$. diamantinum n. sp. and some other species close to Pternaspatha "nigristrigatum group" (Table II).

\section{TABLE I}

Differences between Simulium strigidorsum (Juliaca) and S. diamantinum (Laguna del Diamante)

\begin{tabular}{ll}
\hline strigidorsum & diamantinum n. sp. \\
\hline Shorter, wing length: 3.1-3.2 mm & Longer, wing length: 3.4-3.9 mm \\
Abdominal pollinosity lead-gray opaque & Lighter gray \\
$\begin{array}{l}\text { Abdomen without 1+1 lateral black spots on } \\
\text { segments (Fig. 32) }\end{array}$ & Abdomen with 1+1 lateral black spots on tergites III- \\
Legs darker & V (Figs 4-5) \\
Fore legs entirely dark brown & Legs more yellowish \\
& $\begin{array}{l}\text { Fore legs brown with dorsal surface of femur and } \\
\text { basal half of tibia light brown }\end{array}$ \\
$\begin{array}{l}\text { Hind legs with femur mostly dark brown; basal } \\
\text { half of tibia dark yellowish; second to apical tarsal } \\
\text { segments all black (Fig. 33) }\end{array}$ & $\begin{array}{l}\text { Hind legs with femur lighter with basal third } \\
\text { yellowish; basal half of tibia light yellowish; second } \\
\text { to apical tarsal segments with base light brownish } \\
\text { (Fig. 2) }\end{array}$ \\
\hline
\end{tabular}


TABLE II

Characters of Simulium pichi, S. dureti, S. diamantinum, S. horcochuspi and S. deagostinii

\begin{tabular}{|c|c|c|c|c|c|}
\hline Species & pichi & dureti & diamantinum & horcochuspi & deagostinii \\
\hline \multicolumn{6}{|l|}{ FEMALE } \\
\hline Scutum hairs:adpressed & + & + & - & + & \pm \\
\hline dense & + & + & - & - & \pm \\
\hline bright color & silvery & silvery & silvery & silvery & \\
\hline \multicolumn{5}{|c|}{$1+1$ lateral black spots on T.III-V } & + \\
\hline Wing length & $2.4-2.9$ & $3.2-3.7$ & $3.4-3.9$ & $2.9-3.6$ & $3.3-3.5$ \\
\hline Calcipala & small & small & absent & absent & absent \\
\hline Claws subbasal tooth & short & short & large & short & large \\
\hline $\begin{array}{l}\text { Ratio length/width } \\
\text { posterior basitarsus }\end{array}$ & 6.4 & 6.7 & $7.2-7.6$ & $5.8-6.0$ & 6.6 \\
\hline $\begin{array}{l}\text { MALE } \\
\text { Ratio length/width } \\
\text { posterior basitarsus }\end{array}$ & 3.8 & $3.2-3.4$ & 3.3 & 3.8 & 3.7 \\
\hline \multicolumn{6}{|l|}{ PUPA } \\
\hline Cocoon & $\begin{array}{l}\text { slipper-shaped, } \\
\text { light brown thin } \\
\text { translucent }\end{array}$ & $\begin{array}{l}\text { shoe-shaped, } \\
\text { large antero- } \\
\text { ventral bridge, } \\
\text { thick not } \\
\text { translucent }\end{array}$ & $\begin{array}{l}\text { shoe-shaped, } \\
\text { large antero- } \\
\text { ventral bridge, } \\
\text { thick not } \\
\text { translucent }\end{array}$ & $\begin{array}{l}\text { slipper-shaped, } \\
\text { brownish, gray } \\
\text { leaden sheen, } \\
\text { very thin, trans- } \\
\text { lucent (Fig. 34) }\end{array}$ & $\begin{array}{c}\text { shoe-shaped, } \\
\text { large antero- } \\
\text { ventral bridge, } \\
\text { translucent }\end{array}$ \\
\hline Maximum gill length & $1.2-1.6$ & $2.0-2.5$ & $2.2-3.0$ & $1.8-2.3$ & $2.0-2.4$ \\
\hline No. of frontoclypeus platelets & $600-900$ & $600-800$ & $500-1000$ & 400 & $600-800$ \\
\hline $\begin{array}{l}\text { No. of frontal trichomes } \\
\text { on each side }\end{array}$ & 3 & 12 & $5-15$ & $3-4$ & $4-6$ \\
\hline $\begin{array}{l}\text { No. of facial trichomes } \\
\text { on each side }\end{array}$ & $1-2$ & 4 & $3-6$ & 1 & 3 \\
\hline $\begin{array}{l}\text { No. of thorax trichomes } \\
\text { on each side }\end{array}$ & 60 & 150 & $160-220$ & $60-85$ & $35-80$ \\
\hline Trichomes length & $0.08-0.12$ & $0.10-0.19$ & $0.24-0.35$ & 0.25 & $0.17-0.18$ \\
\hline $\begin{array}{l}\text { LARVA } \\
\text { Maximum length }\end{array}$ & 6.7 & 8.5 & 8.5 & 8.0 & 8.0 \\
\hline Cephalic apotome spots & $\begin{array}{l}\text { light brown, } \\
\text { positive pattern } \\
\text { concolorous with } \\
\text { head apotome }\end{array}$ & $\begin{array}{l}\text { dark brown, } \\
\text { negative }\end{array}$ & $\begin{array}{l}\text { light brown, } \\
\text { negative not } \\
\text { well defined }\end{array}$ & $\begin{array}{l}\text { light brown, } \\
\text { negative not } \\
\text { well defined }\end{array}$ & $\begin{array}{l}\text { dark brown, } \\
\text { negative well } \\
\text { defined }\end{array}$ \\
\hline $\begin{array}{l}\text { Proportion of antennal } \\
\text { articles I-III }\end{array}$ & 1:1.1:0.9 & $\begin{array}{l}1: 1.3-1.4: \\
0.7-0.8\end{array}$ & $\begin{array}{l}1: 1.8-1.9: \\
1.2-1.3\end{array}$ & $1: 1.6-1.7: 1.2$ & $\begin{array}{l}1: 1.3-1.5: \\
0.8-1.0\end{array}$ \\
\hline $\begin{array}{l}\text { No. of mandibular } \\
\text { secondary teeth }\end{array}$ & $6-8$ & $3-4$ & $4-6$ & 6 & $4-5$ \\
\hline $\begin{array}{l}\text { Lateral setae of } \\
\text { hypostomium }\end{array}$ & 11 & $11-14$ & $15-17$ & $13-14$ & $14-15$ \\
\hline $\begin{array}{l}\text { Ratio length of hypos- } \\
\text { tomium/hypostomial bridge }\end{array}$ & $1 / 1.1$ & $1 / 3$ & $1 / 4-1 / 5$ & $1 / 2$ & $1 / 3$ \\
\hline $\begin{array}{l}\text { No. of rows in the } \\
\text { crochet ring }\end{array}$ & $83-92$ & $84-92$ & $94-100$ & 110 & $95-98$ \\
\hline No. of hooks & 18 & 17 & $15-17$ & 22 & $17-18$ \\
\hline
\end{tabular}


No. of anal gill lobules on each lobe

No. of teeth in the pseudopod comb

Habitat altitude (m)

Provinces

\begin{abstract}
0
\end{abstract}

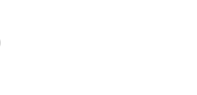

42

10-200

Chubut,

Santa Cruz

1,800-4,300

0

5-7

43-54

Jujuy, Salta

1,200-3,400

San Juan,

Mendoza, Neuquén

Endemism area

Patagonia

Puna

Puna, Patagonia
4-6

37

$10-300$

Santa Cruz,

Tierra del Fuego
Data on Table II show that pichi, dureti, diamantinum, horcochuspi and deagostinii are very closely related species which can be distinguished by some morphological characters and different distributions. S. diamantinum can be distinguished from the other species by several distinctive characters such as: female abdomen with $1+1$ small, narrow and short, black lateral spots on tergites III-V, well isolated from the tergites median black spot and leaving a wide white transverse band before the posterior border, scutum hairs not adpressed, narrower posterior basitarsi, longer pupa gill, higher number of frontal and thorax trichomes, longer thoracic trichomes, and in the larva a longer second antennal segment, more lateral setae on the hypostomium, and a shorter hypostomial bridge in relation to hypostomial length.

Another Pternaspatha species that requires further study is $S$. nigristrigatum Enderlein particularly the currently unknown immature stages. This species is sympatric with $S$. (Pt.) bachmanni Wygodzinsky \& Coscarón. S. nigristrigatum was originally described from one male and five females from Neuquén, (Neuquén Province, Argentina). Later, Wygodzinsky and Coscarón (1967) studied more material from localities at near Neuquén, where bachmanni is also present.

S. bachmanni was described in the female, male, pupal and larval stages from a locality 40 $\mathrm{km}$ east of the nigristrigatum type locality in the Negro river, formed by the confluence of the Neuquén and Limay rivers. Posteriorly has been collected in the Limay river always at the same locality (Coscarón \& Wygodzinsky 1972). S. bachmanni was considered by Wygodzinsky and Coscarón (1967) as a new species based mainly on ornamental and morphological differences with nigristrigatum female.

S. bachmanni is a very well known species with a distribution on Río Negro High and Medium Valleys, Colorado, Chubut and Tecka rivers at different localities (Coscarón 1991). It is a distinctive species in the immature stages, particularly the morphological characters of the pupa such us the absence of platelets on the thorax and frontoclypeus and the sparse thoracic trichomes of which there are about 10 [in other Simulium (Pternaspatha) species always are more than 10]. Ornamental differences that differenciate bachmanni and nigristrigatum occur particularly on the female abdomen, which has 1+1 sub-lateral, whitish spots as is shown in Wygodzinsky (1958, Fig. 21), with a curved anterior border, or in Wygodzinsky and Coscarón (1967) and Coscarón (1991) showing a more acute anterior border, as also occurs in the nigristrigatum female type specimen revised recently. Simulium bachmanni also shows similar intraspecific variations in abdominal ornamentation (Wygodzinsky \& Coscarón 1967, Coscarón 1991) but the more common condition is shown in Fig. 35. The male nigristrigatum lectotype (Stone 1962) does not show morphological and ornamental differences with S. bachmanni. Male basitarsi proportions and morphology of the genitalia of $S$. nigristrigatum (Fig. 36) are similar to those seen in S. bachmanni.

Previous collections in the Limay, Neuquén and Negro rivers, and other Patagonian creeks, produced immature stages indistinguishable from $S$. bachmanni. Based on this evidence we consider $S$. (Pternaspatha) bachmanni Wygodzinsky \& Coscarón 1967 to be a junior synonym of $S$. (Pternaspatha) nigristrigatum Enderlein 1930.

\section{AKNOWLEDGEMENTS}

To Dr H Schumann from the Zoologisches Museum of the Humboldt University, Berlin, for the loan of type material, to Escribano Benito Perez from Comision Mendoza del Valle de Uspallata for help in transporting the authors to Laguna del Diamante, and to Prof. Nélida Caligaris for the illustrations.

\section{REFERENCES}

Coscarón S 1981. Insecta, Diptera, Simuliidae: 105 pp., 15 pl., fotos. In RA Ringuelet. Fauna de Agua Dulce de la República Argentina 38. Fasc. 1.

Coscarón S 1991. Insecta, Diptera, Simuliidae: 304 pp., 67 pl., In ZA de Castellanos. Fauna de Agua Dulce de la República Argentina 38. Fasc. 2. 
Coscarón S, Matta A 1982. Notas sobre Simúlidos Neotropicales X. Sobre dos nuevas especies de "jerjeles" del género Simulium Latreille del Norte de Chile (Simuliidae, Diptera, Insecta). IDESIA (Chile) 6: 49-61, figs.

Coscarón S, Wygodzinsky P 1972. Taxonomy and distribution of the Black Fly subgenus Simulium (Pternaspatha) Enderlein (Simuliidae, Diptera, Insecta). Bull Amer Mus Nat Hist 147: 201-240, figs.

Enderlein G 1930. Der heutige Stand der Klassifikation der Simuliiden. Arch Klassif Phylog Ent 1: 77-97.

Stone A 1962. Notes on the types of some Simuliidae
(Diptera) described by Enderlein. Ann Ent Soc America 55: 206-209.

Wygodzinsky P 1958. Notas y descripciones de Simuliidae patagónicos y andinos (Diptera). Acta Zool Lilloana 16: 121-148.

Wygodzinsky P, Coscarón S 1967. A review of Simulium (Pternaspatha) Enderlein (Simuliidae, Diptera). Bull Am Mus Nat Hist 136: 1-116.

Wygodzinsky P, Coscarón S 1979. Description of Black Fly of the subgenus Simulium (Pternaspatha) from the High Andes of Ecuador (Simuliidae, Diptera). Amer Mus Novitates 2670: 1-9, figs. 